\title{
Heritage Values and Communities. Examining Heritage Perceptions and Public Engagements
}

\author{
Veysel Apaydin \\ Department Culture, Communication and Media, Institute of Education, University College \\ London, London, United Kingdom.
}

To cite this article: Apaydin, V. 2017. Heritage Values and Communities: Examining Heritage Perceptions and Public Engagements. Journal of Eastern Mediterranean Archaeology and Heritage Studies. Vol-5, No: 3. 349-363.

\begin{abstract}
Communities construct themselves differently, depending on the diverse socio-political environments which they inhabit. This also impacts their worldviews and their perceptions of heritage. In addition, in nation states such as Turkey, heritage perceptions are shaped by state ideology through formal education, which often transfers one-sided and programmatic knowledge to students, mostly focusing on the official history of the state. As a result, communities are deprived of opportunities to learn about 'other' pasts, such as those concerned with prehistory and minorities in antiquity. Community archaeology projects and local museums hold an important role in closing the gap created by formal education methods, and can have a profound impact on community perceptions of the past. At the same time, the exchange of knowledge with communities can be troublesome. This article examines heritage perceptions and discusses the importance of public archaeology and local museums by comparing three different sites and their associated communities.
\end{abstract}

\section{Introduction}

Public archaeology is any area of archaeological activity that interacts or has the potential to interact with the public (Schadla-Hall 1999: 147). Types of public archaeology can include: formal education whereby history is taught to students; community archaeologies, education and public outreach, particularly those practiced by museums and archaeological projects; archaeological digs involving community collaboration; and through the media, such as newspapers, magazines and TV, all of which can have a great impact on forming and shaping the public's understanding of the past. Arguably, history education in schools has the greatest impact on people's worldviews, collective consciousness, and heritage perceptions (Apaydin 2016a). In nation states, particularly those constructed on the premise of single ethnicity, history education in schools is usually one-sided and programmatic, silencing aspects of the past which do not align closely with the national agenda, such as the histories of minority groups and prehistory (Apaydin 2016a). The strong effect of state ideology (which, in the case of Turkey, is filtered both through nationalism and religion) limits community understandings of heritage and exposure to different dimensions of the past, which foments neglect towards certain archaeological sites as well as plundering and looting. Fortunately, regional community archaeologies, usually run by museums and excavation projects, have become more common recently and play a significant role in bridging the gap between overarching, official history narratives and individual archaeological sites. These community projects hold a central role in offering opportunities 
for locals to access knowledge about the past. Additionally, museums located in the vicinity of archaeological sites allow local communities to establish direct and immediate links with heritage, which in turn leads to the protection and preservation of the sites in question.

The aim of this article is twofold: (a) understand how heritage perceptions are constructed within local communities and (b) consider which factors have the largest impact on such perceptions. In order to achieve these aims, this paper examines the cases of three archaeological sites, Çatalhöyük, Ani and Hattuşa. Çatalhöyük is a famous and significant Neolithic site, Ani is well known for its medieval Armenian architecture, and Hattusa is a renowned site and the monumental capital of the Hittite Empire in the second millennium BCE. I chose these sites not only because of their fame and the fact that they represent different time frames and cultures of the past, but also because the contemporary communities near them are dissimilar in terms of their socio-political structures.

In this study, I used qualitative interviews and participant observations to assess local perceptions and the effect of community archaeologies and local museums on the former. The data were gathered during fieldwork campaigns in summer seasons between 2010 and 2013. The participant observations helped me understand the daily life of locals, the internal dynamics and values of the communities at issue, and how these values tint perceptions of heritage. The interviews allowed me to understand local opinion on heritage broadly and deeply, and query the involvement of communities with local archaeology projects as well as their expectations and suggestions. The interviews included questions such as: "What is your understanding of the past and ancient materials?"; "What does heritage mean to you?"; "Do you consider Çatalhöyük/Ani/Hattuşa as your heritage?"; "Do archaeologists communicate sufficiently with locals?"; "Are current public-archaeology projects adequate?"; "Do you feel the local museum is useful?"; "What else can be done for better protection of the sites?" In total, 50 people, who were mostly men-due to the conservative societal structures in these regions it was difficult to interview women one-onone-participated in the interview process.

\section{Overview of the Sites and Their Respective Communities}

In this section I briefly discuss archaeological work at the sites and the sociopolitical and ethnic structure of the current communities living nearby. All the communities at issue are socially traditional, the level of education is generally low (mostly primary and secondary school degrees), and women are not prominent in public life. The main reason for that is the strong conservative lifestyle and influence of religion.

\section{The Neolithic Site of Çatalhöyük and the Conservative Community of Konya and Nearby Villages}

Çatalhöyük is located in the Konya plain in south-central Anatolia, about $50 \mathrm{~km}$ southeast of the city of Konya (Fig. 1). Excavations commenced in the 1960s, when the site was first discovered by the British archaeologist, James Mellaart. The site became internationally known because of its size, complex structure and status as one of the earliest Neolithic sites outside the Fertile Crescent. Excavations ceased in 1965, and resumed in 1993 as the Çatalhöyük Research Project, which is led by lan Hodder (e.g., 1996, 2000a). Hodder and his team have not only focused on the excavations but also regional surveys, conservation, 
community archaeology and education programs, aiming for multivocal, reflexive, contextual, and interactive approaches to archaeology (e.g., Hodder 2000a, 2000b). Çatalhöyük became a UNESCO World Heritage Site in 2012. Konya is probably one of the most conservative regions in Turkey, with the majority of the city population being dedicated Muslims committed to daily religious practice and prayer (see Shankland 1999). The city has many historical mosques and shrines dedicated to significant leaders of Islam and is mostly populated by people of Turkish ethnic origin. The people living in the villages in the vicinity of Çatalhöyük are similar to those in Konya in that village social structures, family structures, and gender roles are shaped by Islamic tradition (Apaydin 2015: 144-45).

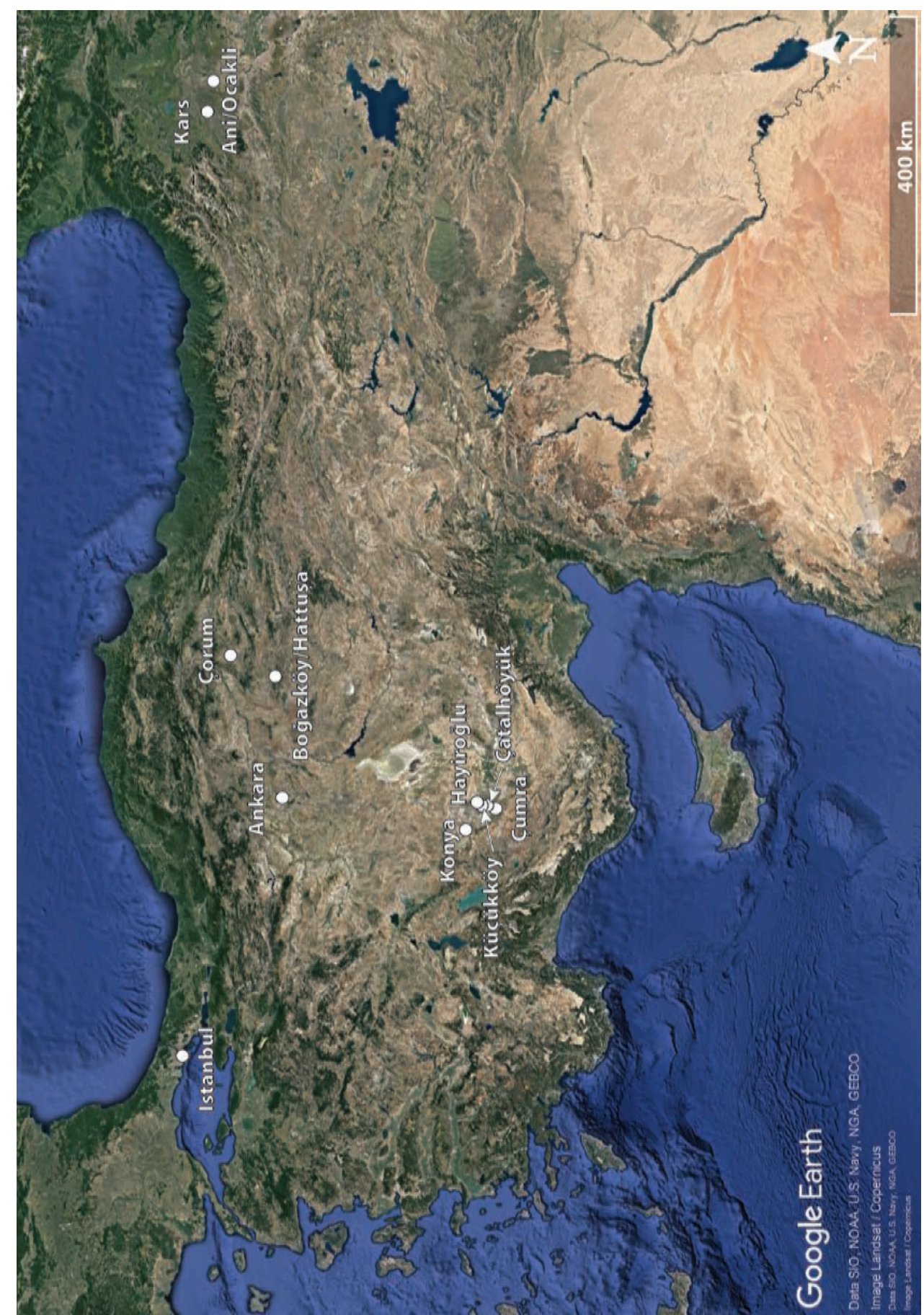

Fig. 1. Locations of the archaeological sites and associated communities. (Map by R. Stidsing.) 


\section{The Historical Armenian Site of Ani and the Contested Landscape of Kars}

Ani is located on the border of modern Turkey and Armenia in Kars (see Fig. 1). Excavations there began in 1892 by the Russian scholar Nicholas Marr together with Armenian scholars, T. Toramanyan and I. A. Orbeli, and continued under Marr's directorship until 1917 (e.g., Marr 1934). Since the second half of the twentieth century, Turkish archaeological institutions have worked at the site (e.g., Balkan 1965). Although the site has a considerable amount of Seljuk, Islamic, Arabic, Persian, and Georgian heritage, the site is famous for its medieval Armenian architecture, particularly the churches (see Strzygowski 1918; Cowe 2001; Manuelian Der 2001). The site was added to the UNESCO World Heritage List in 2016. Although the region of Kars used to be quite multicultural, nowadays it is mostly inhabited by people of Turkish and Kurdish origins. Here, in contrast to Konya, nationalism rather than religion is the most important force shaping the social and political structure of the region, because it has been historically contested between the Ottoman Empire, Russia, and Armenians (Apaydin 2015: 147-48).

\section{The Hittite Capital of Hattuşa and the Turkish Communities of Çorum and Boğazköy}

The site of Hattuşa is located near the city of Çorum in the small town of Boğazköy/Boğazkale (see Fig. 1). Archaeological excavations go back to the nineteenth century after the French explorer Charles Texier discovered the remains of the city in 1834 . The German Archaeological Institute and the German Orient Society began joint excavations after World War I. Since then, the German Archaeological Institute has run excavations in Hattuşa (e.g., Bittel 1969; Seeher 2002). It is also a World Heritage site. Çorum and Boğazköy are populated with Turkish people. The region is one of the strongholds of nationalism and religion, which also shapes the world-view of the local communities (Apaydin 2015: 153-54).

\section{Community: Meaning, Value, and Perception}

What is community? This is perhaps one of the most difficult questions to answer and has been one of the most well researched areas in anthropological studies (see Barth 1969; Geertz 1973; Anderson 1982; Hall 1996; Harvey 2002). Undoubtedly, all communities center on certain ideas and values that define them (see Cohen 1985) and the outlook of individual people within them: social environment (whether family or community) is one of the strongest influences in shaping belief and educating children (Dewey 2009: 17). Since communities have values and experiences that uniquely shape their worldview, a particular community may perceive the past in different ways than another, especially in rural areas. Ethnic homogeneity is a relatively recent development in Turkey, the outcome of systematic state policy since its establishment in 1923, drawing on the notion of 'Turkishness' and Islamic values. Nationalism has shaped communities in many parts of the world and played an important role during the construction of nation states (Hobsbawn 1992: 10), particularly during the nineteenth and twentieth centuries. One of the differences from ethnogenesis in other parts of the world is that in Turkey religion has been a very influential factor, sometimes in conflict with nationalism. Religion is quite effective in shaping the political structure of societies, as it helps construct normative beliefs ('what is and what ought to be') and justifies social organization and spiritual values (Geertz 1983). 


\section{Çatalhöyük}

Great work has been done by the Çatalhöyük Research Project in terms of heritage education programs, which run every year of the field season for 4 weeks. Approximately 5,000 children have attended these education programs in the last decade (see Apaydin 2016b). Community engagement projects include meetings and festivals held in collaboration with the locals who live in close proximity to the site (see Atalay 2012). However, a recent study that focused on the evaluation of these programs revealed that public engagement and heritage education is still necessary, preferably from a bottom-up perspective (see Apaydin 2015, 2016b). The inhabitants of Konya and villages near Çatalhöyük understand the past along specifically religious dimensions, emphasizing Ottoman history and the history of Islam. Most of the community members do not identify with the culture of Neolithic Çatalhöyük (see Figs. 2 and 3). Most members of this community hold similar views, suggesting the prevalence of traditional values and overall homogeneity of beliefs about the past. While it is important to protect and preserve the Islamic and Ottoman heritage and it is only natural that people will value the particular version of the past that reflects and legitimizes their worldview, the lack of the community's identification with the prehistoric site of Çatalhöyük is largely the outcome of statesupported school education, which prioritizes family, national, and religious identity. By contrast, prehistoric and other eras of antiquity, which are seen as largely unrelated to contemporary Turkish identity, are given little coverage (Apaydin 2016a). As a member of this community stated:

[...] Mevlana Celaleddin Rumi1 and his mausoleum are very significant for us. Therefore, we protect and preserve it; we go there very often to pray. It is important for us because it gives us spiritual support that is most important to our lives [. . .].

The comment clarifies why community members do not see Çatalhöyük as 'their' heritage and do not see it as sufficiently important: Since the site is unrelated to Islam, it is not relevant to their everyday lives or spirituality. While the task of archaeologists and heritage specialists is not to impose their own beliefs on the public, rather to help communities understand why all facets of the past are in fact relevant to contemporary life, it is clear that regular schooling and religious tradition within a very conservative community are limiting in this direction. That said, small numbers of people within the community, who have worked at the site as laborers, do value Çatalhöyük as their heritage. 


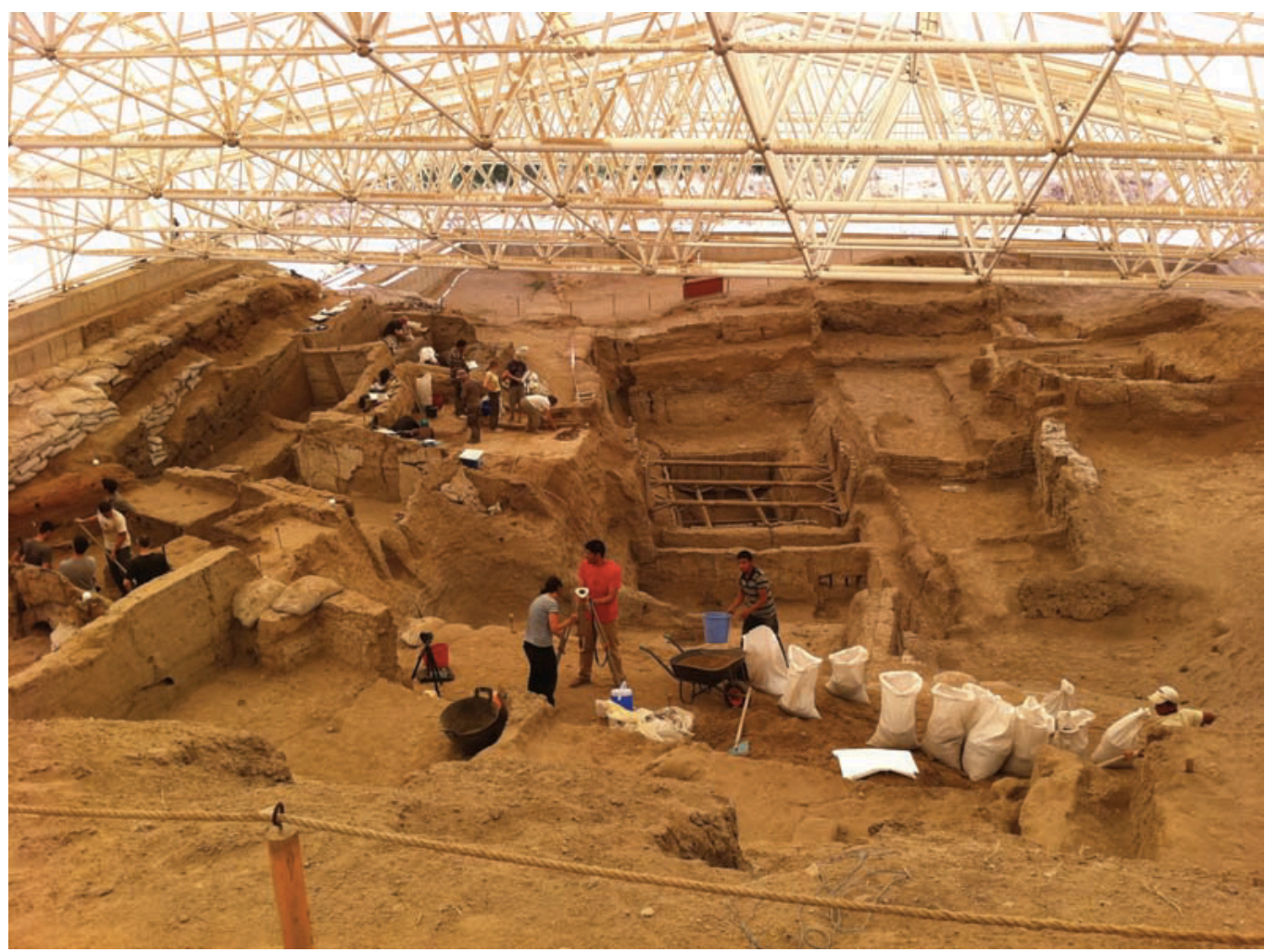

Fig. 2. Çatalhöyük mudbrick houses in South Mount. Photo was taken during the excavation season, directed by lan Hodder, in 2011. (Photo by V. Apaydin.)

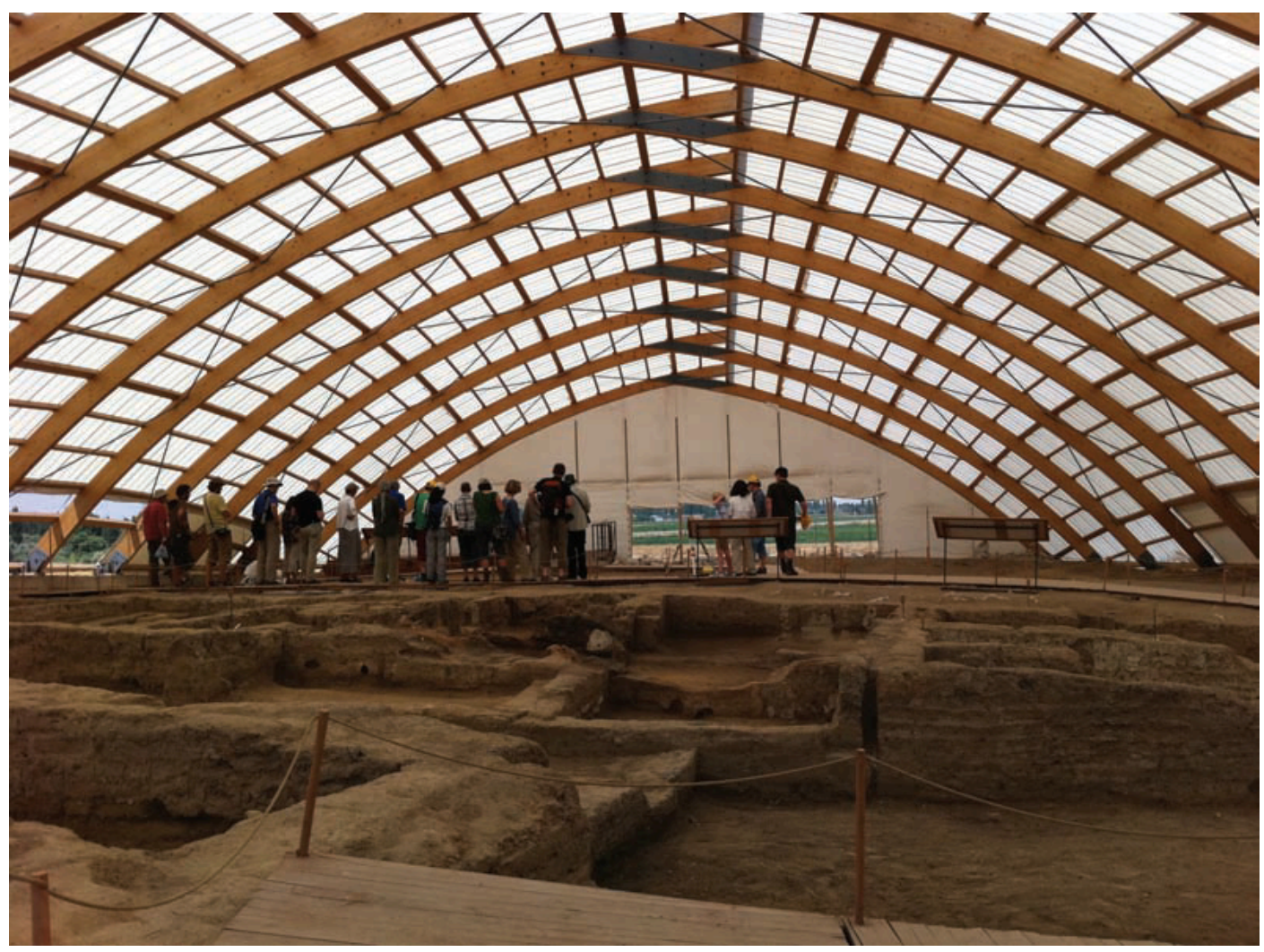

Fig. 3. Çatalhöyük mudbrick houses in East Mount. (Photo by V. Apaydin.) 
The city of Kars is mainly Turkish, with a Kurdish minority. Most people in the village of Ocakli/Ani describe themselves as being of Turkish origin. Interestingly, the interviews with the participants revealed that many of the inhabitants were brought in from other parts of Turkey to live there (see Yeğen 2009) following the Ottoman and Russian war in 1918. Before that, the region was probably one of the most multicultural cities in Turkey (see Akçayöz et al. 2007). Today, remnants of this multiculturalism can only be seen in some of the architecture of the city. As Pamuk (2004) illustrates in his famous novel Snow, there was a large Armenian population in Kars during the Ottoman period, which is evidenced by the remains of churches and characteristic Armenian stone houses in Kars. Although Ani has a considerable number of remains from the Seljuk Empire, most of the monuments there were built during the Armenian Kingdom in the tenth and eleventh centuries CE (see Figs. 4 and 5). Today, most of the Armenian, Russian, and Christian architectural heritage has been destroyed and some of the churches have been converted into mosques, which has damaged the original architecture of the historical churches (Apaydin 2015: 280).

By contrast to Çatalhöyük, the communities around Ani and their perceptions of the past are thus strongly oriented towards ethnic issues. The conflicts over ownership that arose in the early twentieth century, location on the border with Armenia (with which Turkey has had a political dispute for decades), and conflict between the Ottoman Empire and Russia in 1918, are some of the factors that historically influence local perspectives on the past. The fact that Ani and Kars are on the border with Armenia, a 'frontier of identities,' also colors local historical discourse with a nationalist agenda. In general, it is important to keep the nationalist discourse as strong as possible in border cities (Donnan and Wilson 1999: 5), because borders are an arbiter of the identity of nation states (Anderson 1996: 1-3); there are also issues regarding historical ownership of lands. Comments made by this community during the interviews suggest official, state discourses remain powerful: they actively shape people's views about the region's past and have a homogenizing effect. For example, many inhabitants uniformly deny the existence of the Armenians and their heritage in the region:

What [we] know about the past of this region is that it was always Turkish, only the Russians occupied it for several years in the past but we took over our lands again. It is everything that [we] inherited from our ancestors. For instance, the glorious histories of the Ottoman Empire and Turks in the past of these lands [. . . Ani is also important for us and it is [our] past because the monuments and architecture, which contain much Turkish architecture, of the city were built in the reign of Sultan Alparslan who conquered Anatolia in 1071 and afterwards by Turks [. . . there is not such a past and history of Armenians in the region [. . . ] Ani and the region have always been Turkish and Islamic [. . .].

These excerpts emphasize the history of the Ottoman Empire and the Turks, neglecting or denying the historical presence of the Armenians or Georgians in the region, and projecting 'Turkishness' back to time immemorial. In the second excerpt, the villager claims that the monuments and other architecture of Ani were built during the reign of Sultan Alparslan of the Seljuk Empire, sharply denying the Armenian past in the region altogether. Such 
sentiments indicate the continuing strong influence of state official discourse and align with the official view of history that people received during their primary, secondary, and high school education (Apaydin 2016a). The silencing of alternative pasts witnessed in these statements is hardly surprising since, as Anderson (2001: 38) puts it, "our relationship to the past is today far more political, ideological, contested, fragmentary and even opportunistic than in ages gone by."

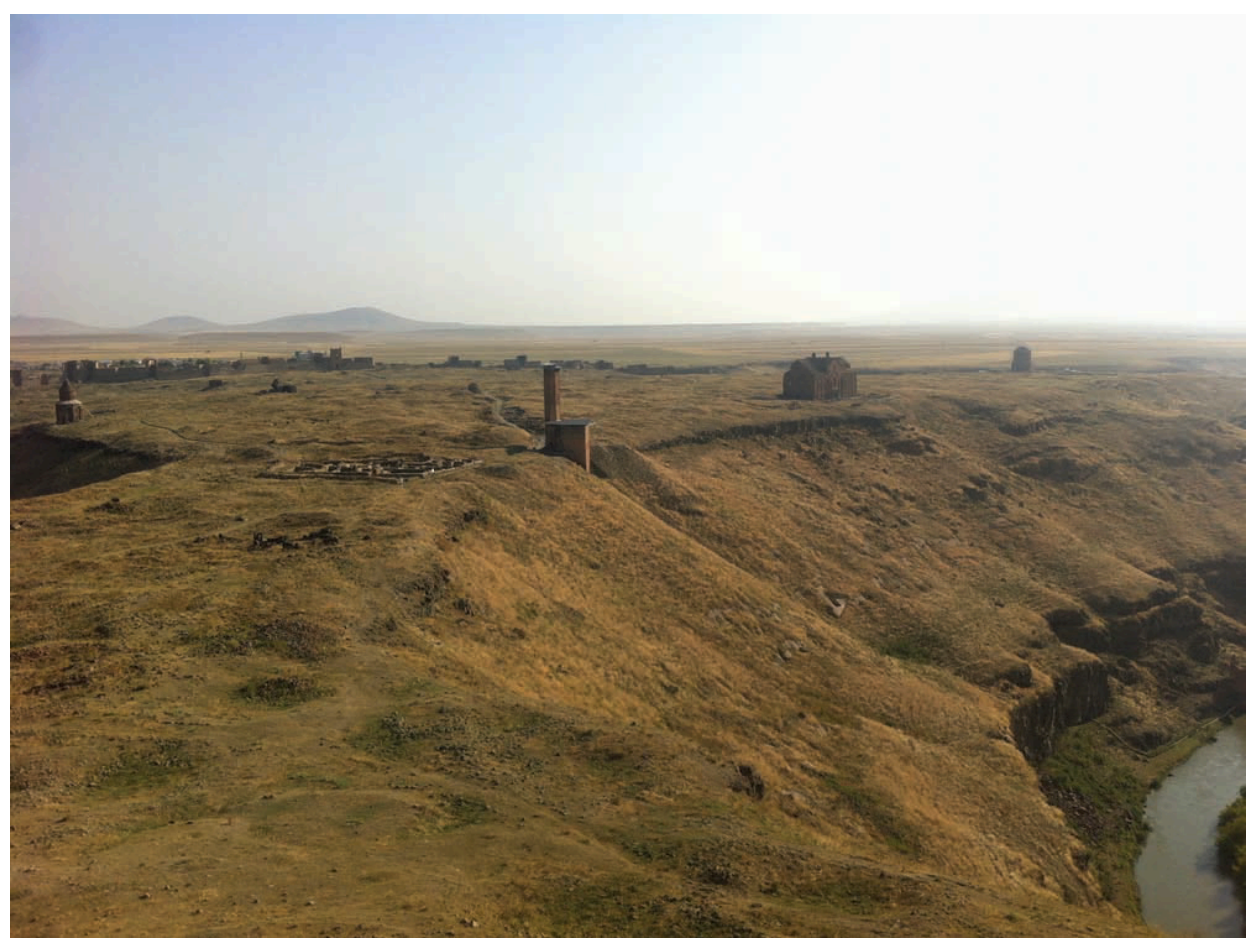

Fig. 4. Ani overview. (Photo by V. Apaydin.)

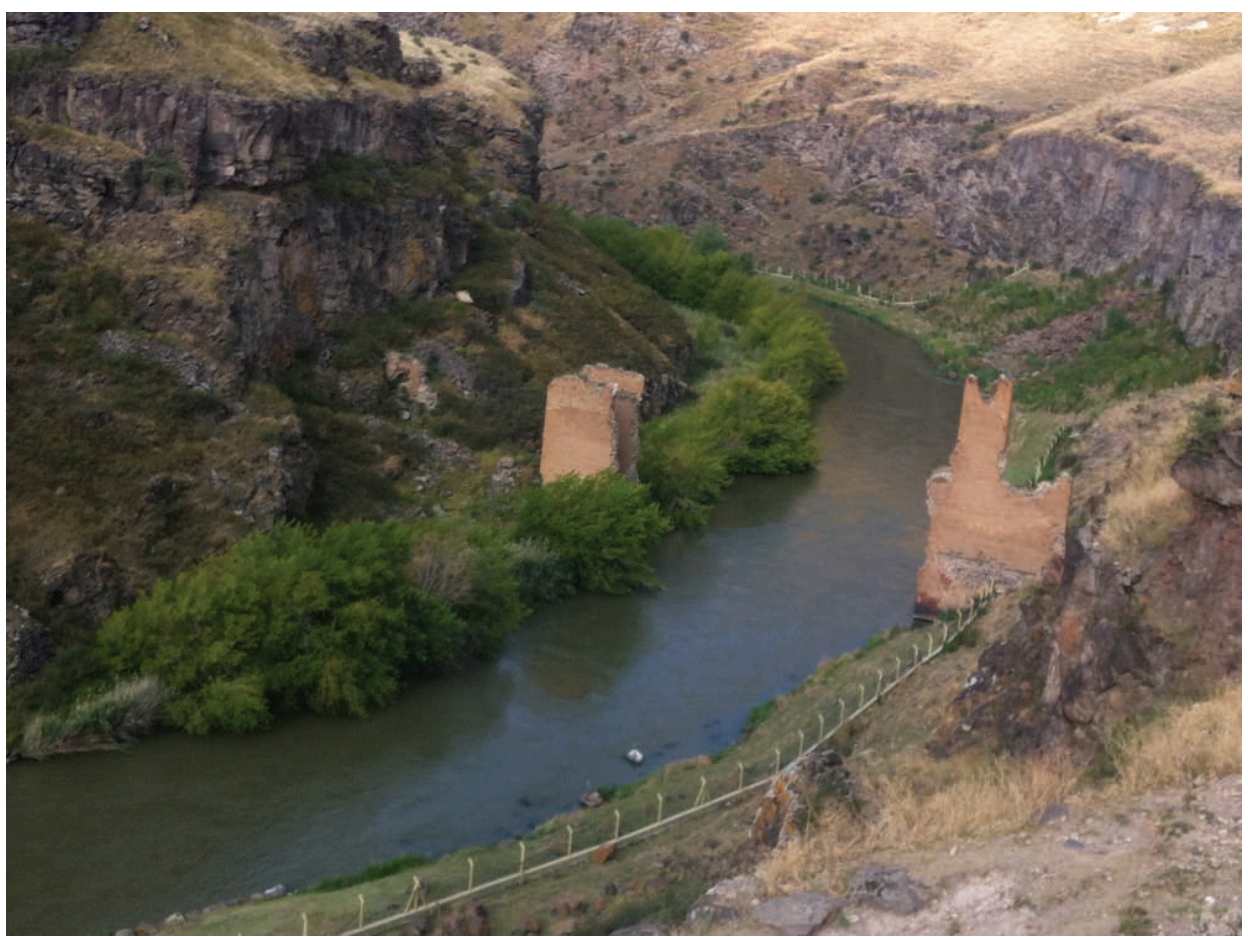

Fig. 5. Ani ancient Silk Road bridge and the border of Armenia and Turkey. (Photo by V. Apaydin.) 
Whereas the archaeological and historical heritage of Çatalhöyük and Ani is at odds with the values of the contemporary communities in those areas, the site of Hattuşa is embraced by the public and its culture, thus embedded in contemporary identity. The main reason for this is that the historical narrative of the Hittites, including their capital of Hattuşa, contributed to identity building during the Turkish Republic (although this is no longer the case). In the 1930s, the history of Turkey was rewritten to support its ideological elements to shape and configure the knowledge of the past among its citizens (Ersanli 2003). During this period, the Turkish state sought to expand its roots in Anatolia by arguing that the Hittites were Turks, in order to claim the right to own the land of Anatolia. In order to prove this argument, congresses were organized (Atakuman 2008) and systematic excavations of Hittite sites were initiated. As a result, Hittite archaeological sites are culturally embedded in their respective contemporary communities; in fact, awareness about these sites is very high among the public. As Boğazköy/Boğazkale inhabitants state,

[. . .] our history is significant [. . . Hattuşa is also very important for us, it is part of us $[\ldots]$

[.. .] I am Turkish but I believe that Hittites were our ancestors [. . ] I have been working in the excavations for 20 years, therefore, I have learned a lot about the Hittites' life that is very similar to our lifestyle [. . . ] and I am proud that I am from Hattuşa [...]

[...] Hattuşa is also important and part of our lands and us; therefore it must have better protection [...]

Another important reason for Hattuşa's recognition as part of the contemporary heritage is that this culture has been publicized very well. For instance, an important symbol of the Hittites, the sun disk, is presented to the public as a symbol of the Turks, not only in Boğazköy/Boğazkale, but also in other cities such as the capital, Ankara (Fig. 6).

Governmental institutions (such as the state bank) and commercial entities (e.g., one of the biggest biscuit factories in the country) utilize the name 'Eti'2 (Mertcan and Bozbay 2007: 178) and the Hittite sun emblem. Without a doubt, harnessing the power of images, symbols, connotations and good 'marketing' of the Hittites has profoundly affected how people think about this ancient culture (Fig. 7). The political and ideological importance of Hattuşa is also attested in the form of projects undertaken by the local governor. For instance, the reconstructed city wall at the entrance to the site bears a Turkish flag, as well as Hittite kings and symbols (Figs. 8), consolidating the connection between the Hittite past and the contemporary state (Fig. 9). 


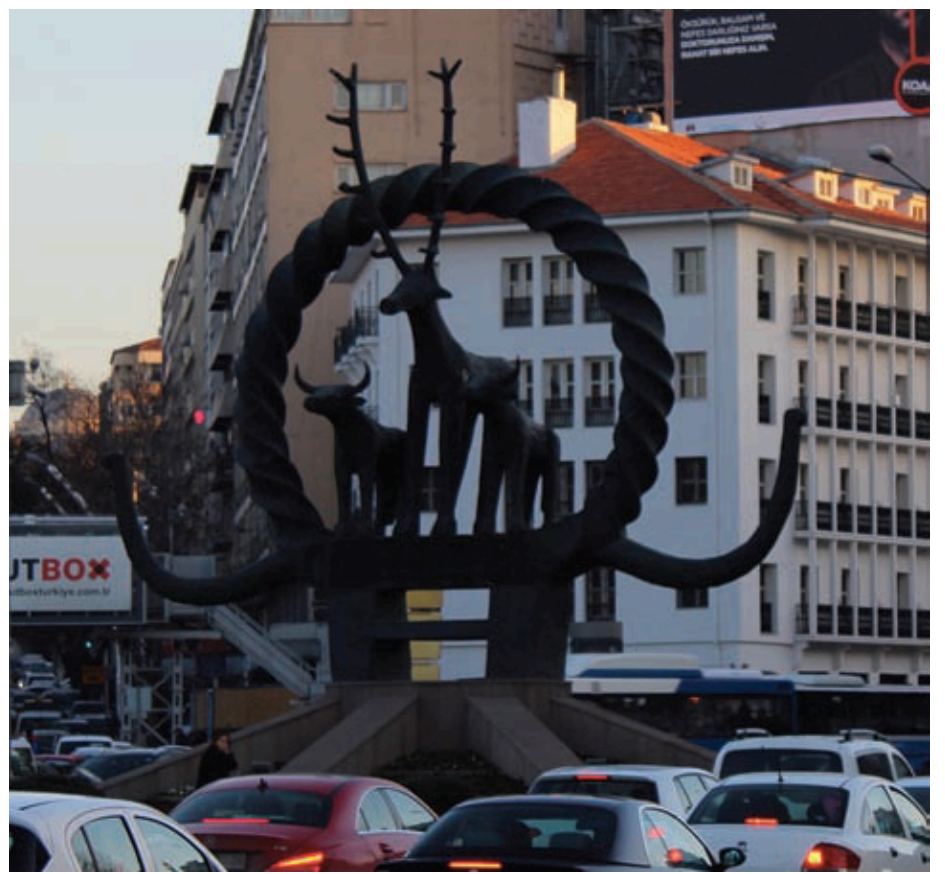

Fig. 6. Hittite sun disc, located in the centre of the city, at Ankara. (Photo by V. Apaydin.)

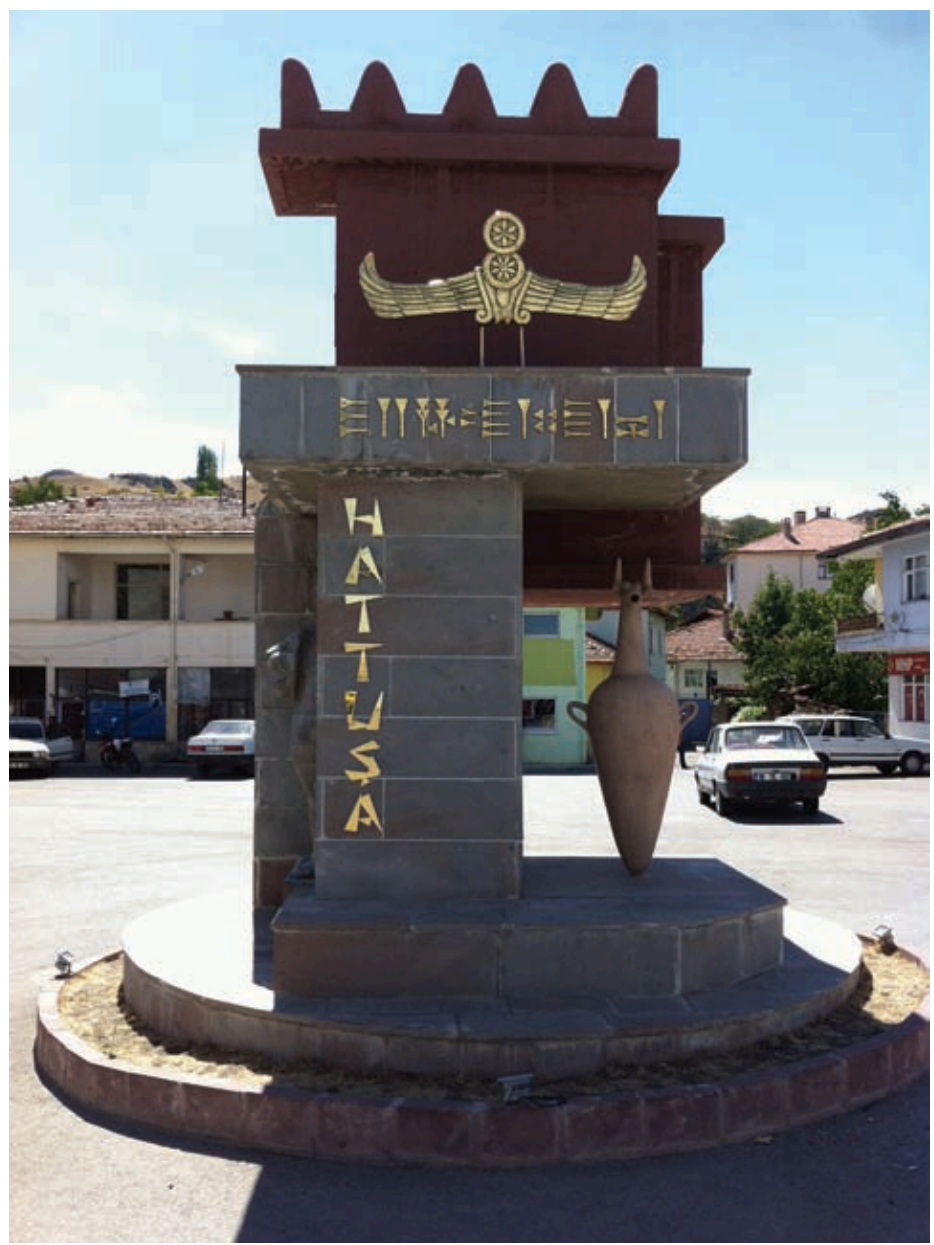

Fig. 7.Boğazköy/Boğazkale main square with Hittite symbol. (Photo by V. Apaydin.) 


\section{Community Archaeologies: Approach and Practices}

Public archaeology should create opportunities for all people and groups to access the past, increase awareness about heritage, and help overcome prejudice against neglected or silenced aspects of the past. In recent decades, the interest in and numbers of community archaeology projects with such aims have increased all around the world. The importance and impact of this phenomenon (see Nevell and Redhead 2015) and the very definition of 'public archaeologies' (Moshenska and Dhanjal 2011) [End Page 357] have been widely discussed. The role of public archaeology is more significant in countries where formal education about the past is one-sided and overtly political (Apaydin 2016a). Limited knowledge about ancient cultures does nothing to reduce the looting and plundering of archaeological sites; hence excavation projects and museums hold a key role in providing learning opportunities, and public initiatives in local areas and increasing heritage awareness are directly correlated (Fig. 10).

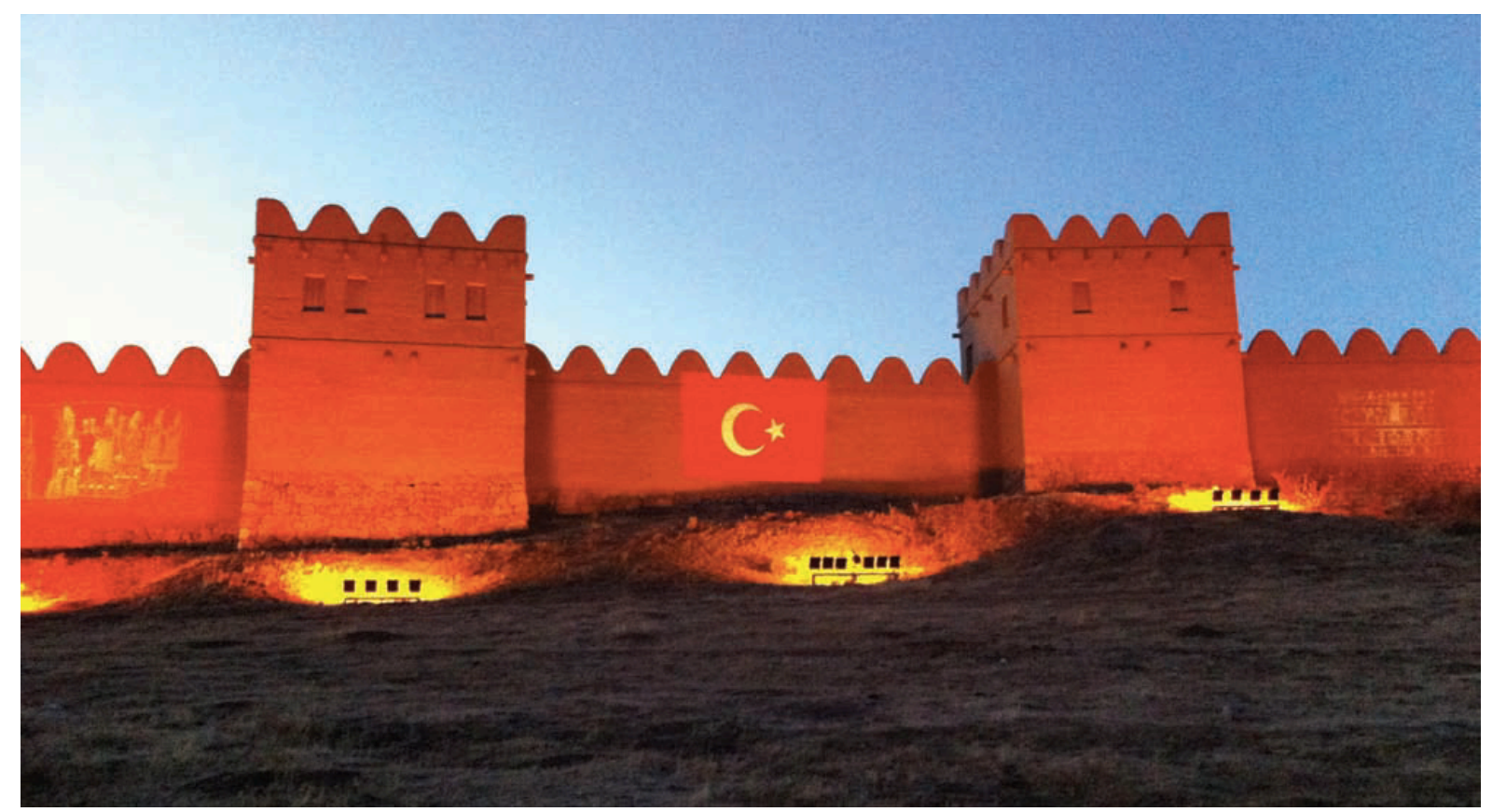

Fig. 8. Reconstructed city walls of Hattuşa with the Turkish flag and fresco of Hittites in 2013. (Photo by V. Apaydin.)

On the other hand, such initiatives may face practical problems. To begin with, local authorities reporting to the state may be resistant to adopt public archaeology projects. Even international initiatives, such as the Çatalhöyük Research Project, which has run community-oriented projects for years, have been unable to establish sustained relationships with the broader community (Atalay 2012; Apaydin 2016a, 2016b, 2016c). Comments made by community members during the interviews illustrate some of these difficulties and demonstrate the need for additional, more effective work:

[...] [I]t is true that people are very religious and will not get the benefit from a nonIslamic site, but they would have got historical knowledge, and they would have had 
the benefit of knowing history. If the site was presented to the public well and explained to them, they could still enjoy having Çatalhöyük as a heritage site [. . .].

The main reason for the lack of interest in the site as identified by this respondent, who lives in Çumra, is lack of access to knowledge and insufficient opportunities offered to the public. For example, western/foreign and Turkish scholars who are unfamiliar with the dynamics of regional areas will have little success in explaining a distant past to Islam-oriented communities. Part of the problem in the latter direction is that programs are unsustainable and limited to only several weeks (see Çatalhöyük Archive Reports 3), and there is little continuity. In addition to taking into account the needs of individual communities, the focus of such projects needs to shift, from brief programs tied to the fieldwork schedule, to sustainable training of locals as stewards of the sites in collaboration with local schools and town councils.

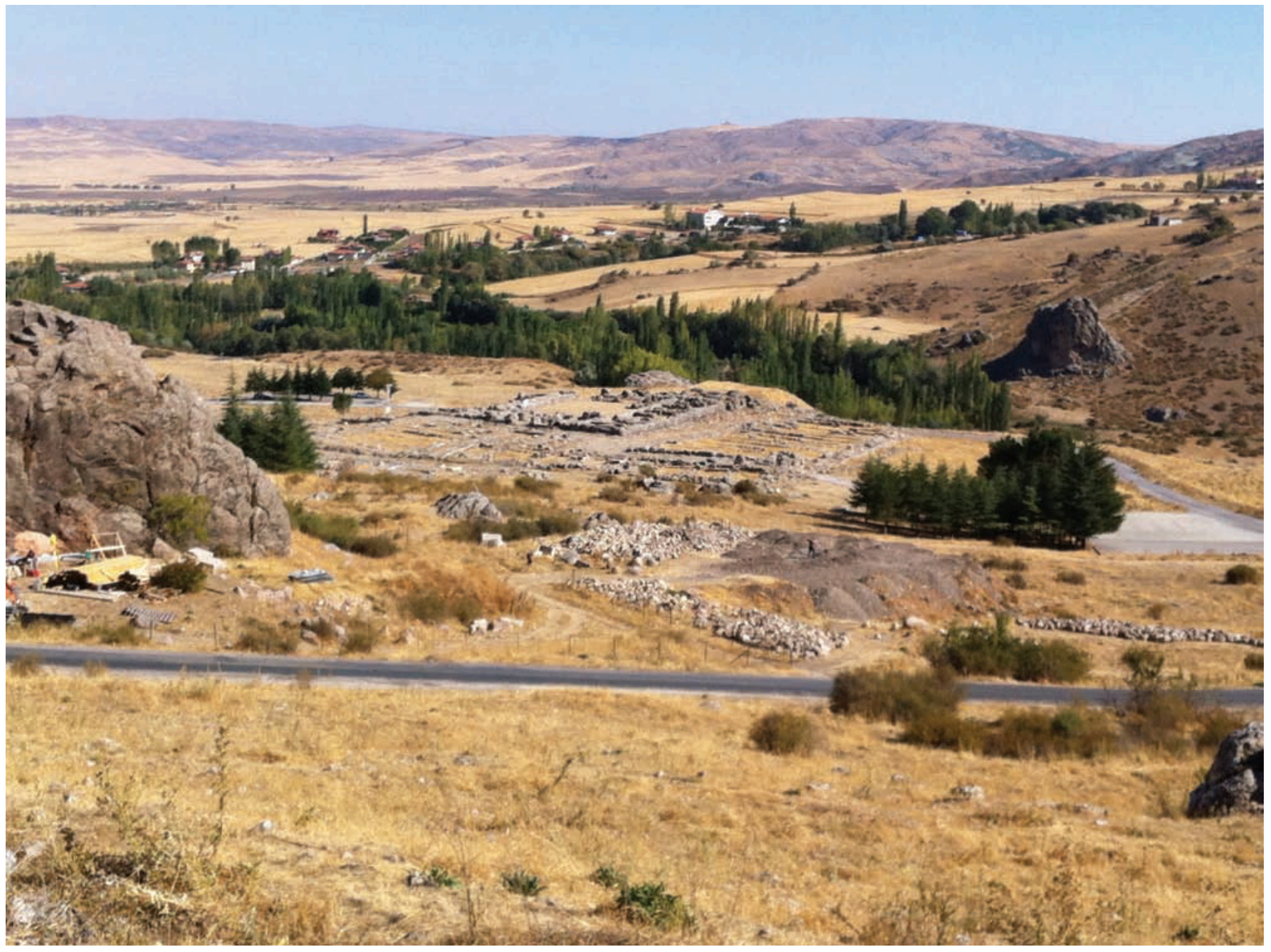

Fig. 9 Overview of Hattuşa and Boğazköy/Boğazkale. (Photo by V. Apayadin.)

Although there has never been a systematic public archaeology program run at Ani, short heritage seminars and education programs organized by the local borough of the city in collaboration with heritage specialists have been conducted almost a decade ago. The interviews, which reveal a doubting attitude towards the authenticity of architectural remains or their Armenian identification, suggest the shortcomings of such programs. As I proposed above, formal education, nationalist propaganda, and state ideology have shaped community perceptions of this heritage. As a TV journalist from Kars, pointed out, 
[...] one of the reasons that locals are manipulated easily is that there are no systematic education programs; people do not have access to information [. . .] if people have the knowledge of other cultures they cannot be easily manipulated.ig. 9. Overview of Hattuşa and Boğazköy/Boğazkale. (Photo by V. Apayadin.)

Communication with the public is of the utmost importance, as it lays the groundwork for integrating professional archaeology and community beyond the basic needs of the former for local labor. In the case of Hattuşa, where we have the advantage of long-term and systematic excavations, archaeologists have integrated their work with the community to a great extent, even though there is no formal public archaeology project run by the excavation team. For instance, the archaeological camp of the excavation team is located in the town which has made interaction with the community much easier. In addition, current and previous excavation directors are and were fluent in Turkish, a fact that also helped to publicize the site to the locals.

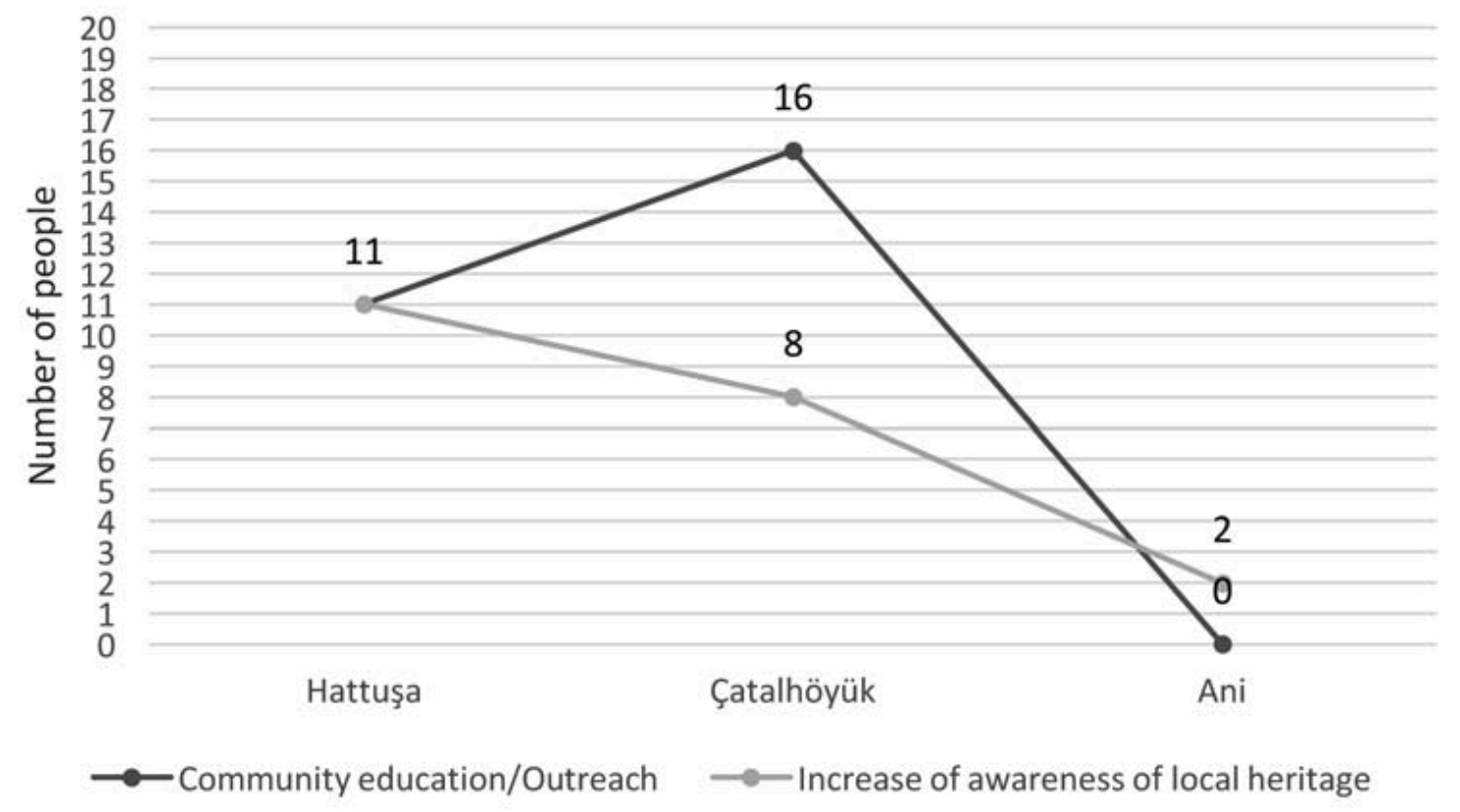

Fig. 10. Correlation between presence of community archaeology projects and increase of community knowledge of and interest in local heritage.

\section{The Role of Local Museums: Seeing and Feeling the Past}

Local museums help increase awareness of sites as well as shape communities' perceptions of heritage positively. Traditionally, museums are a means to articulate the 'cultural essence' of nations, projecting contemporary national identity into the past and constructing it in the process (Macdonald 1998; Aronsson and Elgenius 2011). Museums are considered places where cultural memory is inscribed and exhibited (see Macdonald 2013). Local museums that are an integral part of their respective communities have the potential to escape the nationalist model and have significant impact on increasing heritage awareness among communities. Exhibiting artifacts may increase heritage awareness 
through visual exposure to material culture and relevant information. A multisensory approach to exhibited artifacts, at least with certain objects, may enhance the appeal of museums (through feeling/touching, etc., e.g., Pye 2008).

Even though Çatalhöyük is an archaeological site of international acclaim, a World Heritage site, and a long-term excavation project of 23 years, artifacts produced by this site are sent to the museum of Konya, which is also the site's broader community, but is almost an hour's drive from the local villages. Most of the community members are busy with farming and animal husbandry throughout the year and therefore they rarely have the opportunity to see the exhibits. A majority of villagers pointed out during the interviews that they have seen only artifact pictures, but 'they do not make any sense' to them. One respondent, who has been to Çatalhöyük as a visitor many times and who is very eager to learn more about the site and the artifacts, finds access to the latter is limited. He is not wealthy and does not have the time during the workday to visit exhibits in distant museums:

[. . .] other than the foundations of the mud brick houses, I have never seen anything else. I mean, I have never seen any objects or artifacts. We do not even know where they are.

This lack of artifact access and visibility contributes to the lack of knowledge about, or interest in, archaeological research at Çatalhöyük. Another community member states why a local museum would have been helpful:

[. . .] we also need a local museum that is open and free to locals, which displays artifacts from Çatalhöyük and other sites around here. The museum in Konya is far from here; it takes more than one hour to get there. Since all villagers are farmers here, they are busy and do not have time to go to another city to see stuff from Çatalhöyük. However, if there was a museum here, I could go and visit during my spare time and learn more about the site and its artifacts.

Systematic education programs at local museums could also help dispel concerns among the community that archaeology undermines their religious beliefs.

In a similar vein, the nearest museum to the site of Ani is located in the city, some 45 minutes away. The positive impact of seeing and touching the objects, which I argue are two of the most effective tools for increasing heritage awareness, is also supported by the ways that people who have worked at the site feel about it. These members of the public have developed an immediate connection with the past by working with archaeologists. One of the Ani/Ocakli villagers explains his benefits from working at the site:

I have learned a lot about Ani. I know every single building with its historical background because I worked there for years. However, the locals in the villages around Ani have no knowledge or little knowledge, or they have completely wrong information. 
Of course, not every member of these communities can be employed at the archaeological sites, but the importance of a local museum cannot be overstated as it establishes an immediate rapport with the community.

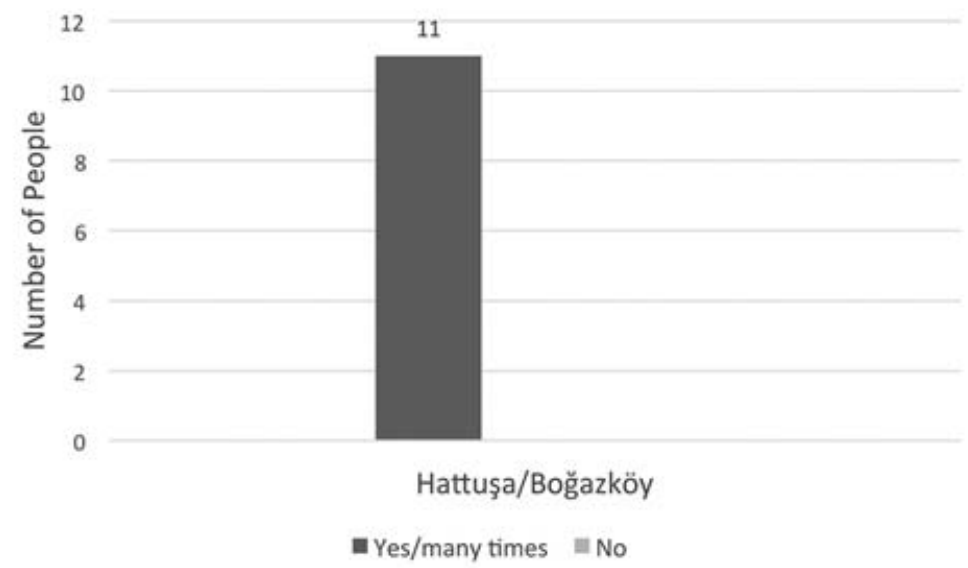

Fig. 11. Interest in and visitors to the local museum at Hattuşa/Boğazköy.

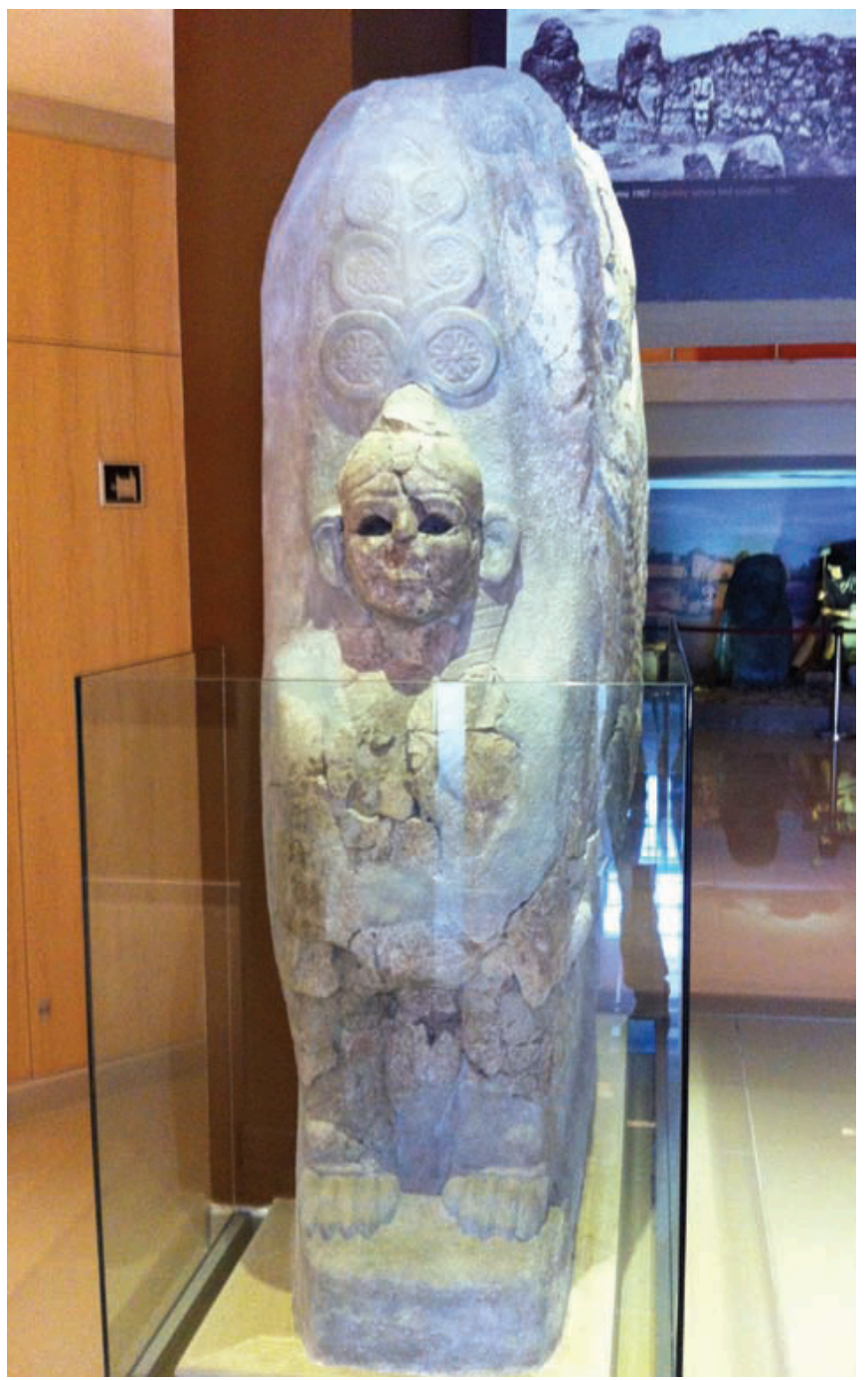

Fig. 12. Hattuşa local museum. (Photo by V. Apaydin.) 
By contrast, at Hattuşa all community members visited the site at least once or a few times (Fig. 11), as it is located at the center of the village of Boğazköy/Boğazkale less than $1 \mathrm{~km}$ from the site (Fig. 12). Access to artifacts in this museum is explicitly credited by the locals as a positive factor in their understanding of the past, as well as a source of pride:

[. . .] [B]efore, Hattuşa did not have a museum [. . .] after it was established, my family and I have been to the museum many times [. . . ] it has given us the chance to see artifacts from Hattuşa. Before it was established, the artifacts were taken to the Ankara museum [. . .] because of the local museum I have learned more about the Hittite life style [. . . ].

[...] I have been to the local museum many times, and a couple of times to the Çorum museum [. . . I I am very proud that we have a museum here. If we did not have a museum here, I would not have had the chance to see the Sphinx that was returned from Germany in 2013.

These interview excerpts clearly indicate the effect of the local museum in increasing heritage awareness; unsurprisingly, the destruction and plundering of the area around Hattuşa has ceased, although smuggling of artifacts used to be frequent in the region. The local museum, which is also very easily accessible to local schools, has an enduring, crossgenerational education effect as children have the ability to conceptualize better the history and past cultures in this region, and their significance in contemporary culture. Indicatively, almost all community members at Çatalhöyük and Ani answered 'yes' to the question "would you be interested in seeing the artifacts from the site and would you take part in museum activities if you had a local museum nearby?" (Fig. 13).

\section{Conclusion}

The social environment of communities shapes their values and filters the understanding of the past (e.g., Gutek 1998: 163). At the same time, public archaeology projects and local museums can nuance and enrich these emic understandings, not to attempt to change or impose values but encourage communities to learn about other pasts. Given the concerns about the ineffectiveness of extant or past projects raised both by local voices and myself, the aims and methodology of these projects should be reconsidered and take into account the needs and practical, socioeconomic constraints of communities.

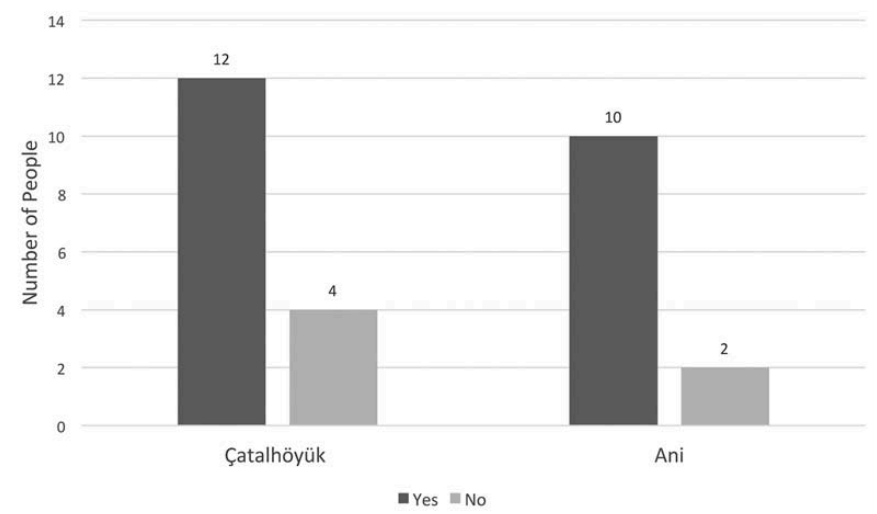

Fig. 13. Interest in having a local museum at Çatalhöyük and Ani. 
Local participation at every stage of archaeological projects should be encouraged. In fact, local communities should be at the center of any decision-making process that is relevant to heritage sites. This is important in two ways: First, encouraging communities to take part in the decision-making process will allow locals to learn more about it and protect the past in a more effective way; secondly, it is an ethical imperative. The heritage sites themselves perform an important role in the daily lives of locals, as they inhabit them and invest them with personal meaning, memories etc. Local communities are not simply stakeholders but 'right holders' (see International Work Group for Indigenous Affairs 20124; Apaydin 2016c). There needs to be more regular communication between archaeologists and locals. The improvement of communication between the two groups can help overcome many of the problems discussed in this paper. Finally, the existence of local exhibits will allow communities to interact with at least some of the artifacts on a regular basis, which can have a positive and sustained impact on heritage perception among communities, as demonstrated by the case of Hattuşa. 


\section{References}

Akçayöz, V., T. Çakaş, Y. Öztürkkan, S. Yazıcı, and O. Yurdalan. 2007. Kars Kent Rehberi. Istanbul: Kars Kent Konseyi.

Anderson, B. 1982. Imagined communities: Reflections on the Origin and Spread of Nationalism. London: Verso.

- - . 2001. Western Nationalism and Eastern Nationalism: Is There a Difference That Matters? New Left Review 9:31-42.

Anderson, M. 1996. Frontiers: Territory and State Formation in the Modern World. Cambridge: Polity.

Apaydin, V. 2015. The Presentation of the Past: Pitfalls and Potentials-Education and Archaeology, Heritage and Communities in Turkey-The Case Studies of Çatalhöyuk, Ani and Hattusa. PhD diss, University College London.

- - . 2016a. Development and Re-Configuration of Heritage Perception: History Textbooks and Curriculum in Turkey. AP: Online Journal in Public Archaeology 6:27-50.

- - . 2016b. Effective or not? Success or Failure? Assessing Heritage and Archaeological Education Programs-The Case of Çatalhöyük. International Journal of Heritage Studies 22:828-43. DOI: 10.1080/13527258.2016.1218912.

- - . 2016c. Economic Rights, Heritage Sites and Communities: Sustainability and Protection. Complutum 27:369-84. dx.doi.org/10.5209/CMPL.54751.

Aronsson, P., and G. Elgenius, eds. 2011. Building National Museums in Europe 1750-2010: Conference Proceedings from EuNaMus, European National Museums: Identity Politics, the Uses of the Past and the European Citizen, Bologna 28-30 April, 2011. EuNaMu Report 1, Linköping Electronic Conference Proceedings 64. Linköping, Sweden: Linköping University Electronic Press.

Atakuman, Ç. 2008. Cradle or Crucible: Anatolia and Archaeology in the Early Years of the Turkish Republic (1923-1938). Journal of Social Archaeology 8:214-35.

Atalay, S. 2012. Community-Based Archaeology: Research with, by and for Indigenous and Local Communities. Berkeley, CA: University of California Press.

Balkan, K. 1965. 1965 Yılı Ani kazıları Hakkında Kısa Rapor. Türk Arkeoloji Dergisi 14:103-08.

Barth, F. 1969. Introduction. In Ethnic Groups and Boundaries: The Social Organisation of Culture Difference, ed. F. Barth, 9-38. London: Allen \& Unwin.

Bittel, K. 1969. Boğazköy: The Excavations of 1967 and 1968. Archaeology 22:276-79.

Cohen, A. 1985. The Symbolic Construction of Community. London: Routledge. 
Cowe, P. S., ed. 2001. Ani. World Architectural Heritage of a Medieval Armenian Capital. University of Pennsylvania Armenian Texts and Studies 16. Leuven: Peeters.

Dewey, J. 2009. Democracy and Education. New York: Merchant Books.

Donnan, H., and T. M. Wilson. 1999. Borders: Frontiers of Identity, Nation and State. Oxford: Berg.

Ersanlı, B. 2003. Iktidar ve Tarih. Türkiye'de “Resmi Tarih” Tezinin Oluşumu (1929-1937). Istanbul: Iletişim Yayınları.

Geertz, C. 1983. Centers, Kings, and Charisma: Reflections on the Symbolics of Power. In Local Knowledge: Further Essays in Interpretive Anthropology, 121-46. New York: Basic Books.

- - , ed. 1973. The Interpretation of Cultures. New York: Basic Books.

Gutek, G. L. 1988. Philosophical and Ideological Perspectives on Education. Englewood Cliffs, NJ: Prentice Hall.

Hall, S., ed. 1996. Questions of Cultural Identity. London: Sage.

Harvey, D. L. 2002. Agency and Community: A Critical Realist Paradigm. Journal for the Theory of Social Behaviour 32:163-94. doi:10.1111/1468-5914.00182.

Hobsbawn, E. J. 1992. Nations and Nationalism since 1780: Programme, Myth, Reality. Cambridge: Cambridge University Press.

Hodder, I. 2000b. Developing a Reflexive Method in Archaeology. In Towards Reflexive Method in Archaeology: The Example at Çatalhöyük, ed. I. Hodder, 3-24. Cambridge: McDonald Institute for Archaeological Research.

-- - ed. 1996. On the Surface: Çatalhöyük 1993-95. British Institute of Archaeology at Ankara Monograph 22. Cambridge: McDonald Institute for Archaeological Research.

- - , ed. 2000a. Towards Reflexive Method in Archaeology: The Example at Çatalhöyük. McDonald Institute for Archaeological Research: Cambridge.

MacDonald, S. 1998. Exhibitions of Power and Powers of Exhibition: An Introduction to the Politics of Display. In The Politics of Display: Museums, Sciences, Culture, ed. S. MacDonald, 1-21. London: Routledge.

- - . 2013. Memorylands: Heritage and Identity in Europe Today. London: Routledge.

Manuelian Der, L. 2001. Ani: The Fabled Capital of Armenia. In Ani: World Architectural Heritage of a Medieval Armenian Capital, ed. P. S. Cowe, 1-12. University of Pennsylvania Armenian Texts and Studies 16. Leuven: Peeters. 
Marr, N. 1934. Ani, Knizhnaya Istoriya Goroda i Roskopi. Leningrad: Ogiz.

Mertcan, H., and H. Bozbay. 2007. Eti Türkleri. In Özgür Üniversite Resmi Ideoloji Sözlügüu, ed. F. Başkaya and T. Ersoy, 171-94. Ankara: Maki Basım Yayın.

Moshenska, G., and S. Dhanjal. 2011. Introduction: Thinking About, Talking About, And Doing Community Archaeology. In Community Archaeology: Themes, Methods and Practices, ed. G. Moshenska and S. Dhanjal, 1-5. Oxford: Oxbow.

Nevell, M., and N. Redhead, eds. 2015. Archaeology for All. Community Archaeology in the Early 21st Century: Participation, Practice and Impact. Manchester: University of Salford.

Pamuk, O. 2004. Snow. New York: Knopf.

Pye, E., ed. 2008. The Power of Touch: Handling Objects in Museums and Heritage Context. University College Institute of Archaeology Publications. Walnut Creek, CA: Left Coast Press.

Schadla-Hall, T. 1999. Editorial: Public Archaeology. European Journal of Archaeology 2:14758.

Seeher, J. 2002. Hattusha Guide: A Day in the Hittite Capital. Istanbul: Ege Yayınları.

Shankland, D. 1999. Islam and Society in Turkey. Cambridgeshire: Eothen.

Strzygowski, J. 1918. Die Baukunst der Armenier und Europa. 2 vols. Vienna: Schroll.

Yeğen, M. 2009. "Prospective-Turks" or "Pseudo-Citizens": Kurds in Turkey. Middle East Journal 63:597-615. 